ISSN 0258-7122 (Print), 2408-8293 (Online)

Bangladesh J. Agril. Res. 42(4): 647-663, December 2017

\title{
PROFITABILITY OF SANDBAR CROPPING METHOD OF PUMPKIN CULTIVATION IN CHAR LAND AREAS OF NORTHERN BANGLADESH
}

\author{
M. KHATUN ${ }^{1}$, M. A. RASHID ${ }^{2}$, M. A. M. MiAH ${ }^{3}$ \\ S. KHANDOKER ${ }^{4}$ AND M. T. ISLAM ${ }^{5}$
}

\begin{abstract}
The study was undertaken to find out the profitability and export potentialities of pumpkin cultivation in the char lands of Rangpur and Gaibandha district of Bangladesh. A total of 120 pumpkin growers taking 60 farmers from each district were randomly selected for the study. Descriptive statistics was used to analyze cost and return of pumpkin. The Cobb-Douglass production function was used to estimate the coefficients of the various variables analysed and MPP, MVP and resource use efficiency were also used to estimate the efficiency of resource use in the study area. The study revealed that net returns were positive for pumpkin cultivation. However, the higher net return was estimated for Rangpur district (Tk 105,299/ha) compared to Gaibandha (Tk.93, 936/ha). Bangladesh had comparative advantage for producing pumpkin as the estimates of domestic resource cost (DRC) was less than one. The value of DRC for pumpkin was less than unity implied that the production of pumpkin would be highly efficient for export promotion. The estimated results of the CobbDouglass production function showed increasing returns to scale. The results of the efficiency computation indicated that inputs were underutilized. Farmers in the study area used too little input to cultivate pumpkin that means the cost of using inputs is less than the value of marginal product. This suggests that farmers can incur more cost for these inputs to be efficient and then production will be increased.
\end{abstract}

Keywords: Char land, pumpkin, sandbar cropping method, profitability, resource use efficiency.

\section{Introduction}

Climate change and climate variability have an adverse effect on agricultural crop production in Bangladesh. Climate change due to greenhouse gas emissions is expected to increase temperature and alter rainfall patterns (Callinor et al., 2007). Frequent river erosion is occurred and in drought season a large amount of silted-up bodies are raised up. The riverside sand and silt landmasses is known as 'char' in Bengali(Nutritional surveillance project, 2003). The char-lands of the three main rivers the Jamuna-Brahmaputra, Ganges-Padma and Meghna cover some $8,450 \mathrm{~km}^{2}$ ( $6 \%$ of the total land area) with a population of 6 million in

\footnotetext{
${ }^{1-4}$ Scientific Officer and Principal Scientific Officer, Agricultural Economics Division, Bangladesh Agricultural Research Institute (BARI), Gazipur-1701, ${ }^{5}$ Scientific Officer, Pomology Division, Horticulture Research Centre, BARI, Gazipur-1701, Bangladesh.
} 
1992-93 (FAP 16/19, 1994a) and this char population has increased to 12 million (Thompson \& Tod, 1998; EGIS, 2000; Islam et al., 2010; Arifur and Munsur, 2011).These areas are highly vulnerable to river erosion which causes loss of land and makes living in the chars both risky and uncertain. Most of the char dwellers are extreme poor, landless, and marginal farmer. They fight to produce or manage food to eat. To solve this problem, any sustainable tactics is needed that will help the poor households to make optimum use of their available resources and cope with the extreme weather. The Practical Action Bangladesh (PAB), a UK-based internationally reputed NGO, has been assisting the extreme poor families in promoting sandbar cropping, mainly for pumpkin cultivation, in the barren char lands under its Pathways from Poverty (PFP) project since 2009. They introduced a cultivation method named sandbar cropping to produce winter vegetables especially pumpkin in the char lands. Sandbar cropping is a method in which farmers dig holes in sandy land and fill them with manure, compost, and pumpkin seeds. PAB assists farmers by giving all agricultural inputs and technical help. They have also managed storage facilities for the farmers to store pumpkin for getting better price from off-season selling. A total of 5,262 households, 50\% of them are women farmers, cultivated pumpkin on 774 ha of sandy barren char lands and produced 17,790tonnes of the crop and earn Taka 15.22 crore during two years period from 2012 to 2014 (PAB, 2014). From national statistics it is seen that winter pumpkin cultivation area and production are increased over the year (Table 1). With the increase of area and production productivity of winter pumpkin also increased. This may be because of bringing of char land under pumpkin cultivation in Rabi season.

Table 1. Area, production and yield of winter pumpkin in Bangladesh over the year 2005-06 to 2014-15

\begin{tabular}{c|c|c|c}
\hline Year & Area (ha) & Production (MT) & Productivity (MT/ha) \\
\hline $2005-06$ & 11522.27 & 93905 & 8.15 \\
$2006-07$ & 12435.22 & 103840 & 8.35 \\
$2007-08$ & 13060.32 & 107214 & 8.21 \\
$2008-09$ & 13333.2 & 116014 & 8.70 \\
$2009-10$ & 14132.79 & 124534 & 8.81 \\
$2010-11$ & 13686.64 & 121502 & 8.88 \\
$2011-12$ & 14085.83 & 131014 & 9.30 \\
$2012-13$ & 15401.21 & 138896 & 9.02 \\
$2013-14$ & 16046.96 & 166944 & 10.40 \\
$2014-15$ & 17255.87 & 177899 & 10.31 \\
\hline
\end{tabular}

A few studies highlighted on pumpkin production and the livelihood of char people in Bangladesh who are always struggling for their survival. Atanu et. al. (2011) studied on impact assessment of pheromone traps to manage fruit fly on 
sweet gourd cultivation. Nahar et. al. (2016) conducted a research on sweet gourd production under sandbar cropping practices and found that SCP was highly profitable and had a positive impact on livelihood improvement of farmers. They have covered only sundorganj upazila of Gaibandha district. And this study has covered more areas and is more detailed about sandbar cropping method and profitability of pumpkin cultivation by using this method. Rahman and Davis (2005) conducted a survey on rural livelihood and enterprise development opportunities in the Chars, Bangladesh. They showed a brief overview of the agro-economic and natural resource basis, rural livelihoods of the poor, the role of specific sub-sectors and emerging rural economic and enterprise development issues of the Chars. Islam et. al. (2011) conducted research to find out opportunity and challenges for char-land livelihoods sustainability in the Ganges Active Delta. They find out the economy of the char lands are largely based on agriculture, fishing and livestock-rearing. The erosion and vulnerability of the Char-lands in the Padma River channel will be reduced due to Padma bridge construction. The char dwellers livelihoods and socioeconomic improvement will be ensured. The reviews reveal that study on vegetable production on char land for livelihood development of char people is limited and this study has covered these issues.

\subsection{Objectives}

The objectives of this study were as follows:

i. To know the socio-economic and livelihood status of the farmers;

ii. To assess the cultivation practices of pumpkin by using sandbar cropping method;

iii. To estimate the profitability level of pumpkin cultivation by using sandbar cropping method and;

iv. To determine the resource use efficiency of the inputs used by the farmers.

\section{Methodology}

\subsection{Sandbar Cropping Technique}

The sandbar cropping technique is a pit cultivation approach, adapted to the sandbars of char lands to grow pumpkin, squash and watermelon. Pits are dug in the sandbars and are lined with manure and compost. Jute sacks are used in locations where ground water is very poor. Seeds are placed in the pits and are carefully monitored for the next few months with periodic irrigation and nursing as required. At the end of rainy season in mid-November, when water level in the rivers recedes, sandbars start to emerge in the char lands. These sandbars are brought under cultivation using the sandbar cropping technique. 


\subsection{Sampling Procedure}

Two stage sampling procedure was followed to collect sample farmers for this study. At first, two districts Rangpur and Gaibandha were purposively selected from Northern region of Bangladesh on the basis of the availability of such types of farmers. In the second stage, one pumpkin growing upazila from char land of each district was selected on the basis of area and production. Kaunia upazila of Rangpur and Sundorganj upazila of Gaibandha district were selected on the basis of available farmers who cultivate pumpkin on char land using sandbar cropping method. A complete list of pumpkin growers who cultivate in the char lands was collected from PAB officials. The population size of pumpkin growers was 575 in Gaibandha (274 in Sundarganj upazila) and in Rangpur this number was 150 (60 in Kaunia upazila). Finally, a required number of samples were randomly selected from the complete list of pumpkin growing farmers for interview.

\subsection{Sample Size}

The number of sample farmers to be selected is an important question among the researchers. When the population size is known and the researchers are careful of the heterogeneity problem, any number (equal to or) greater than the statistically large sample (of 30 sample units) may be appropriate (Freund and Williams, 1983). However, a total of 120pumpkin growers taking 60 farmers from each district were selected randomly from the list for the study.

\subsection{Data Collection}

The study was mainly based on primary data collected through face to face interview using a pre-tested interview schedule which was conducted through field survey during the month of December to April, 2016.

\subsection{Analytical technique}

The collected data were first edited and tabulated for analysis to fulfill the objectives of the study. Descriptive statistics such as averages and percentages were used in this study. Production function analysis was used to determine the resource use efficiency of the inputs used by the farmers.

\subsubsection{Financial Profitability Analysis}

\section{Measurement of cost and return from crop cultivation}

Gross margin and net farm income analyses (budgeting techniques) were used to estimate cost and returns per hectare and per respondent. The model considered for estimation of cost and returns per hectare and per respondent is implicitly represented below. 
$\mathrm{NFI}=\sum_{i=1}^{n} P_{y i} Y_{i}-\sum_{j=1}^{m} P_{x j} X_{j}-\sum_{k=1}^{k} F_{k}$

Where,

$\mathrm{NFI}=$ Net farm Income

$\mathrm{Y}_{\mathrm{i}}=$ Gross Output $(\mathrm{kg})$

$\mathrm{P}_{\mathrm{y}}=$ Unit price of product $\mathrm{Yi}$ in (Tk.)

$\mathrm{X}_{\mathrm{j}}=$ Quantity of variable input

(where $\mathrm{j}=1,2,3 \ldots \mathrm{n}$ )

$\mathrm{P}_{\mathrm{xj}}=$ Price per unit of variable input (Tk.)

$\mathrm{F}_{\mathrm{k}}=$ Cost of fixed inputs (Tk.)

(where $\mathrm{K}=1,2,3 . . \mathrm{k}$ )

$\Sigma=$ Summation sign

\subsubsection{Economic Profitability Analysis}

\section{Measures of Comparative Advantage}

Comparative advantage or efficiency of producing different crops in Bangladesh agriculture is analyzed here using Domestic Resource Cost (DRC) analysis. This indicator is formally defined as follows:

Domestic resource cost (DRC): The DRC is the ratio of the cost in domestic resources and non-traded inputs (valued at their shadow prices) of producing the commodity domestically to the net foreign exchange earned or saved by producing the good domestically.

Formally DRCs is defined as:

$\mathrm{DRC}=\frac{\text { Cost of domestic resource and non }- \text { traded inputsfor producing per unit of output }}{\text { Value of }}$ Value of tradableoutput - Value of tradable inputs

$\mathrm{DRC}=\frac{\sum \mathrm{F}_{\mathrm{ij}} \mathrm{P}_{\mathrm{j}}^{\mathrm{d}}}{\mathrm{U}_{\mathrm{t}}-\sum \mathrm{a}_{\mathrm{ik}} \mathrm{P}_{\mathrm{k}}^{\mathrm{b}}}$

Where,

$\mathrm{f}_{\mathrm{ij}}=$ Domestic resource and non-traded inputs $\mathrm{j}$ used for producing per unit commodity $\mathrm{i}$

$\mathrm{P}_{\mathrm{j}}^{\mathrm{d}}=$ Price of non-traded intermediate inputs and domestic resource

$\mathrm{U}_{\mathrm{i}}=$ Border price of output $\mathrm{i}$

$\mathrm{a}_{\mathrm{ik}}=$ Amount of traded intermediate inputs for unit production of $\mathrm{i}$

$\mathrm{P}^{\mathrm{b}}{ }_{\mathrm{k}}=$ Border price of traded intermediate input 
If $\mathrm{DRC}<1$, the economy saves foreign exchange by producing the good domestically either for export or for imports substitution. This is because the opportunity cost of domestic resources and non-traded factors used in producing the good is less than the foreign exchange earned or saved. In contrast, if DRC > 1 , domestic costs are in excess of foreign exchange costs or savings, indicating that the good should not be produced domestically and should be imported instead.

\subsubsection{Resource Use Efficiency Analysis}

The double-log function (Cobb-Douglas) provided the best fit and was therefore chosen for the study (Olomla, 1991; Mbata et al., 1993).

Using the ordinary least square (OLS) estimator, the production response function model was expressed implicitly as:

$\mathrm{Y}=\mathrm{f}\left(\mathrm{X}_{1}, \mathrm{X}_{2}, \mathrm{X}_{3}, \mathrm{X}_{4}, \mathrm{Ui}\right)$

Where $\mathrm{Y}=$ the quantity of output in kilograms, $\mathrm{X}_{1}=$ Labour (man-days), $\mathrm{X}_{2}=$ quantity of seed in kilograms, $\mathrm{X}_{3}=$ quantity of bio-fertilizer in kilograms, $\mathrm{X}_{4}=$ quantity of chemical fertilizer in kilograms.

The functional form of the double-log function was ex-pressed as follows:

$\ln \mathrm{Y}=\mathrm{b}_{0}+\mathrm{b}_{1} \ln \mathrm{X}_{1}+\mathrm{b}_{2} \ln \mathrm{X}_{2}+\ldots \ldots \ldots \ldots \ldots \ldots \ldots+\mathrm{b}_{4} \ln \mathrm{X}_{4}+\mathrm{e}$

The marginal physical product (MPP) was given by: MPP $_{i}=b_{i} \times$ $\mathrm{APP}_{\mathrm{i}}$ (3)

Where $b_{i}=$ elasticity's of the various inputs

$\mathrm{APP}_{\mathrm{i}}=\frac{\bar{Y}}{\overline{X_{i}}}$

Where $\mathrm{Y}$ is the mean of output and $\mathrm{X}_{\mathrm{i}}$ is the mean of factor inputs, and $\mathrm{b}_{0}$ and bi are the constant and regression coefficients, respectively.

Using the above specifications and the output and input prices, the marginal value products (MVPs) and resource use efficiency $r$ were computed as follows:

$\mathrm{MVP}_{\mathrm{i}}=\mathrm{MPP}_{\mathrm{i}} \times \mathrm{Py}$

$\mathrm{r}_{\mathrm{i}}=\mathrm{MVP}_{\mathrm{i}} / \mathrm{MFC}_{\mathrm{i}}$

Where, Py and $\mathrm{MFC}_{\mathrm{i}}$, are the unit prices of output and factor input respectively. The decision of whether a resource is used efficiently or not, thus efficiency, is based on the value of $r_{i}$, If $r_{i}$ is equal to one $\left(r_{i}=1\right)$, then the factor input is efficiently utilized. The factor input is over-utilized if $r_{i}$ is less than $1\left(r_{i}<1\right)$ and under-utilized if $r_{i}$ is greater than unity $\left(r_{i}>1\right)$. The significance of each explanatory variable was determined using the t-test. The overall significance was determined by the F-ration. 


\section{Results and Discussion}

\subsection{Socioeconomic status of the farmers}

\subsubsection{Age distribution}

Age of farmers plays an important role in the crop production and better management of the farming activities. The age of the selected pumpkin growers was examined by classifying into four groups: 20-34, 35-49, and 50-64 and above 65 years (Table 3.1). On an average, most of the farmers belonged to the age group 35-49 (69\%) which was 72\% in Rangpur and 65\% in Gaibandha. This implied that majority of the farmers were relatively younger to middle aged and were in a position to put more physical effort for pumpkin cultivation. Farmers belonging to this age group were supposed to have enormous vigor and risk bearing ability.

Table 3.1. Percent distribution of average age of the respondent farmers

\begin{tabular}{c|c|c|c}
\hline Age group (Year) & Rangpur & Gaibandha & All area \\
\hline $20-34$ & 11 & 15 & 13 \\
$35-49$ & 72 & 65 & 69 \\
$50-64$ & 15 & 18 & 17 \\
Above 65 & 2 & 2 & 2 \\
Total & 100 & 100 & 100 \\
\hline
\end{tabular}

\subsubsection{Educational status of the sample farmers}

Literacy may be defined as the ability of an individual to read and write or formal education received up to certain standard. Education helps individuals to become conscious of their environment and develop rational insight into many matters of life. Farmers' education is expected to be an important issue in increasing the production of farming output. Education is likely to influence the farmers to adopt the modern technology and it makes them more capable to manage scarce resources efficiently so that they can earn higher profit. On the basis of education level, the literacy status of the respondent farmers has been categorized into three groups. The categories are (1) can sign, (2) primary and (3) junior. Information on the educational levels of the respondents is presented in Table 3.2. It is observed that, most of the farmers can sign (above 90\%) for both the district. On an average only $7 \%$ of the respondents received primary education, which was $8 \%$ in Rangpur district and 7\% in Gaibandha district and only 2\% of the farmers passed junior and above level in the study areas. It was seen that all the sampled farmers were literate but in national statistics literacy rate $(7$ years +$)$ in Rangpur is $48.55 \%$ and in Gaibandha this is $42.81 \%$ (BBS, 2015).This may be farmers in the study area can do sign from different GO and NGO personnel for perform different agricultural activities. 
Table 3.2. Percent distribution of farmers according to their educational qualification

\begin{tabular}{l|c|c|c}
\hline \multicolumn{1}{c|}{ Level of education } & Rangpur & Gaibandha & All area \\
\hline Can sign & 90 & 92 & 91 \\
Primary & 8 & 7 & 7 \\
Junior & 2 & 1 & 2 \\
Total & $\mathbf{1 0 0}$ & $\mathbf{1 0 0}$ & $\mathbf{1 0 0}$ \\
\hline
\end{tabular}

\subsubsection{Occupational status}

Majority of the sample farmers (93\%) reported that agriculture as their main occupation followed by others (Rickshaw/van puller) as their subsidiary occupation $(4.5 \%)$. Overall, data showed that only $2 \%$ of the sample farmers were engaged in business as their subsidiary occupation (Table 3.3) in the study areas.

Table 3.3. Percent distribution of farmers according to their occupational status

\begin{tabular}{lcc|c}
\hline Occupation & Rangpur & Gaibandha & All area \\
\hline Main Occupation & & & \\
Agriculture & 93 & 93 & 93 \\
Business & 2 & 3 & 2.5 \\
Others & 5 & 4 & 4.5 \\
Subsidiary Occupation & & & \\
Agriculture & 7 & 7 & 7 \\
Business & 2 & 1 & 2 \\
No Profession & 86 & 86 & 86 \\
Others & 5 & 6 & 5 \\
\hline
\end{tabular}

\subsubsection{Household size}

Household size included the number of adult male, adult female and children in the respondent households. Three groups of household size were formed in the study areas. On an average the highest household size group in the study areas was small which consists $75 \%$ among the groups (Table 3.4).

Table 3.4. Percent distribution of farmers according to family members

\begin{tabular}{lcccc}
\hline Family member & Rangpur & Gaibandha & All area \\
\hline Small ( $\leq 4$ person) & 75 & 74 & 75 \\
Medium (5-6 person) & 20 & 22 & 21 \\
Large(> 6 person) & 5 & 4 & 4 \\
Total & $\mathbf{1 0 0}$ & $\mathbf{1 0 0}$ & $\mathbf{1 0 0}$ \\
\hline
\end{tabular}




\subsubsection{Household income}

Annual income of $36 \%$ household ranged from Tk. 50001 to $100000.25 \%$ households had annual income 100001 to 150000 . Only $4 \%$ farmers had annual income above 200000.

Table 3.5. Percent distribution of respondent farmers according to household income

\begin{tabular}{lcccc}
\hline Annual Income (Tk.) & Rangpur & Gaibandha & All area \\
\hline$\leq 50000$ & 25 & 27 & 26 \\
$50001-100000$ & 35 & 37 & 36 \\
$100001-150000$ & 25 & 25 & 25 \\
$150001-200000$ & 10 & 8 & 9 \\
$>200000$ & 5 & 3 & 4 \\
Total & $\mathbf{1 0 0}$ & $\mathbf{1 0 0}$ & $\mathbf{1 0 0}$ \\
\hline
\end{tabular}

\subsubsection{Experience in Pumpkin farming}

Farming experience is an important factor to ensure farm productivity. Farmers who have more experience in farm operations generally attain higher levels of technical efficiency. Technical inefficiency of the production is significantly related to farming experience of the farmers. It was found that $95 \%$ of sample farmers belonged to 3 years of farming experience to cultivate pumpkin through sandbar method and only 5\% belonged to 2 years of farming experience in pumpkin cultivation in the study areas(Table 3.6).

Table 3.6. Percent distribution of farmers according to their experience in sandbar cropping

\begin{tabular}{c|c|c|c}
\hline Years & Rangpur & Gaibandha & All area \\
\hline 2 & 5 & 5 & 5 \\
3 & 95 & 95 & 95 \\
Total & $\mathbf{1 0 0}$ & $\mathbf{1 0 0}$ & $\mathbf{1 0 0}$ \\
\hline
\end{tabular}

\subsubsection{Livelihood status}

Majority (95\%) of the farmers had tin-shed (fence with tin), $80 \%$ had tube well and only 5\% had two wheeler/bicycles. Farmers of Rangpur (43\%) were enjoying electricity but no electricity facilities were observed in Gaibandha district (Table 3.7). On an average majority of the sample farmers (87\%) were used temporary toilet and only $13 \%$ used sanitary toilet. A good number of sample farmers (77\%) had mobile phone indicating that to the sample farmers indicating that use of this good had increased their communication ability in the recent times. On an average the sample farmers expenses Tk.2900, Tk. 250, Tk. 105 and Tk. 275 per 
household per month for food, education, transportation and medicine respectively. Majority of the sample farmers (88\%) stated that for any health related complexity they visited to the village doctor.

Table 3.7. Livelihood status of the farmers

\begin{tabular}{lcc|c}
\hline Particulars & Rangpur & Gaibandha & All area \\
\hline 1. Housing status & & & \\
$\quad$ Tin-shed (Fence with tin) & 95 & 96 & 96 \\
$\quad$ Tin-shed (Fence with bamboo) & 5 & 4 & 5 \\
$\quad$ Other & 5 & 4 & 5 \\
2. Bicycle & 75 & 85 & 80 \\
3. Tube well & 43 & 0 & 22 \\
4. Electricity & & & \\
5. Sanitation status & 18 & 8 & 13 \\
$\quad$ Sanitary toilet & 82 & 92 & 87 \\
$\quad$ Temporary toilet & 7 & 0 & 4 \\
6. Television & 78 & 75 & 77 \\
7. Mobile phone & & & \\
8. Expenditure $\quad$ (Tk./month) & 3200 & 2600 & 2900 \\
$\quad$ Food & 300 & 200 & 250 \\
Education & 125 & 85 & 105 \\
$\quad$ Transportation & 250 & 300 & 275 \\
$\quad$ Medicine & & & \\
9. Doctor's visit (\%) & 15 & 10 & 13 \\
$\quad$ MBBS & 85 & 90 & 88 \\
$\quad$ Village doctor & & & \\
\hline
\end{tabular}

\subsection{Farmers' perception}

Hundred percent sample farmers reported that if they do not get any input support from the NGOs, they will continue to cultivate this profitable crop next year through sandbar method (Table 3.8).

Table 3.8. Farmers' perception about pumpkin cultivation through sandbar cropping without getting support from NGO

\begin{tabular}{l|c|c|c}
\hline District & Yes & No & Total \\
\hline Rangpur & 100 & - & 100 \\
Gaibandha & 100 & - & 100 \\
All areas & 100 & - & 100 \\
\hline
\end{tabular}




\subsection{Adoption of Pumpkin Variety}

Majority of the selected farmers $(61 \%)$ used Buddopathi (Indian) variety followed by Kalopathor (39\%) of pumpkin cultivation in the study areas (Table 3.9).

Table 3.9. Varietal adoption of Pumpkin in the study areas

\begin{tabular}{l|c|c|c}
\hline Name of the variety & Rangpur & Gaibandha & All area \\
\hline Buddopathi & 62 & 60 & 61 \\
Kalopathor & 38 & 40 & 39 \\
Total & $\mathbf{1 0 0}$ & $\mathbf{1 0 0}$ & $\mathbf{1 0 0}$ \\
\hline
\end{tabular}

\subsection{Agronomic Practices}

Planting time of pumpkin cultivation in char areas was November 1-15 and harvesting time was April 1-15. Farmers applied irrigation on an average 38 times due to sandy soil, weeding and spraying 3 times per season in the study areas (Table 3.10).

Table 3.10. Agronomic practices of Pumpkin cultivation in the study areas

\begin{tabular}{lcccc}
\hline Agronomic practices & Rangpur & Gaibandha & All area \\
\hline Time of sowing & Nov. 1-15 & Nov. 1-15 & Nov. 1-15 \\
Planting method (\%) & & & \\
$\quad$ Line & 100 & 100 & 100 \\
No. of weeding & 3 & 2 & 3 \\
No. of irrigation & 40 & 35 & 38 \\
No. of spraying & 3 & 3 & 3 \\
Time of harvesting & April 1-15 & April 1-15 & April 1-15 \\
\hline
\end{tabular}

\subsection{Pattern of input use for pumpkin cultivation}

Farmers employed different level of inputs for pumpkin cultivation. On an average, farmers applied Urea at the rate of $134 \mathrm{~kg} / \mathrm{ha}$, TSP $107 \mathrm{~kg} / \mathrm{ha}$, and MoP $86 \mathrm{~kg} / \mathrm{ha}$. It was observed that among the chemical fertilizers, farmers used highest amount of urea in both the districts (Table 3.11). Farmers used 122 mandays per hectare of human labour for pumkin cultivation, which were 125 mandays for Rangpur district and 118 man-days for Gaibandha district. In the study areas, farmers applied irrigation, pesticides and weeding for pumpkin cultivation.

Table 3.11. Per hectare input use pattern of Pumpkin cultivation

\begin{tabular}{l|c|c|c}
\hline \multicolumn{1}{c|}{ Inputs } & Rangpur & Gaibandha & All area \\
\hline Human labour (man-day) & 125 & 118 & 122 \\
Seed (kg) & 1.07 & 1.07 & 1.07 \\
Bio-fertilizer (ton) & 12.89 & 11.93 & 12.41 \\
Urea (kg) & 134 & 134 & 134 \\
TSP $(\mathrm{kg})$ & 107 & 107 & 107 \\
MoP $(\mathrm{kg})$ & 86 & 86 & 86 \\
Boron $(\mathrm{kg})$ & 2.68 & 2.68 & 2.68 \\
Furadan (kg) & 5 & 5 & 5 \\
\hline
\end{tabular}




\subsection{Cost and Returns of Pumpkin Cultivation}

\subsubsection{Variable cost of production}

The variable cost of production included the costs of human labour, mechanical power, seed, chemical fertilizers, irrigation and pesticides. Both cash expenses and imputed value of family supplied inputs were included in the variable cost. The estimated total variable cost for pumpkin production was Tk. 65,476 and Tk. 61,619 per hectare in Rangpur and Gaibandha district respectively. These costs shared $91 \%$ and $92 \%$ of the total cost of production respectively. The highest variable cost was incurred by the Rangpur district due to use of higher level of inputs. Among the cost items, human labour was the major cost item which shared $44 \%$ of the total cost (Table 3.12). The second highest cost item was irrigation which accounted for about $15 \%$ of the total cost. For all variable costs, cowdung accounted for about $9 \%$ of the total cost and ranked third in cost item. Pesticides cost for both the districts were more or less similar.

\subsubsection{Fixed cost of production}

Rental value of land was considered as fixed cost of production for pumpkin. The cost of this item was Tk. 6,435 and Tk. 5,545 per hectare which accounted for about $9 \%$ and $8 \%$ for Rangpur and Gaibandh district respectively of the total cost of production (Table 3.12). Therefore, a little bit variation was found in fixed cost for both the districts.

Table 3.12. Per hectare cost of Pumpkin cultivation in the study areas

\begin{tabular}{l|c|c|c|c|c|c}
\hline \multirow{2}{*}{ Cost Items } & \multicolumn{2}{|c|}{ Rangpur } & \multicolumn{2}{c|}{ Gaibandha } & \multicolumn{2}{c}{ All area } \\
\cline { 2 - 7 } & (Tk./ha) & $(\%)$ & $($ Tk./ha $)$ & $(\%)$ & (Tk./ha) & $(\%)$ \\
\hline A. Variable costs & & & & & & \\
$\quad$ Cost of land preparation & 1510 & 2.10 & 1495 & 2.23 & 1503 & 2.16 \\
Human labour & 31250 & 43.46 & 29500 & 43.92 & 30375 & 43.68 \\
Cost of seed & 1503 & 2.09 & 1503 & 2.24 & 1503 & 2.16 \\
Bio-fertilizer & 6444 & 8.96 & 5964 & 8.88 & 6204 & 8.92 \\
Chemical fertilizers & & & & & & \\
$\quad$ Urea & 2144 & 2.98 & 2144 & 3.19 & 2144 & 3.08 \\
$\quad$ TSP & 3424 & 4.76 & 3424 & 5.10 & 3424 & 4.92 \\
$\quad$ MoP & 1376 & 1.91 & 1376 & 2.05 & 1376 & 1.98 \\
$\quad$ Boron & 322 & 0.45 & 322 & 0.48 & 322 & 0.46 \\
$\quad$ Furadan & 600 & 0.83 & 600 & 0.89 & 600 & 0.86 \\
Cost of irrigation & 10933 & 15.20 & 9738 & 14.50 & 10336 & 14.86 \\
Cost of pesticides & 4686 & 6.52 & 4345 & 6.47 & 4516 & 6.49 \\
IOC@ 6\% for 4 months & 1284 & 1.79 & 1208 & 1.80 & 1246 & 1.79 \\
Total variable cost & 65476 & 91.05 & 61619 & 91.74 & 63548 & 91.39 \\
B. Fixed costs & & & & & & \\
$\quad$ Land use cost & 6435 & 8.95 & 5545 & 8.26 & 5990 & 8.61 \\
Total fixed cost & $\mathbf{6 4 3 5}$ & 8.95 & $\mathbf{5 5 4 5}$ & 8.26 & 5990 & 8.61 \\
C.Total cost (A+B) & $\mathbf{7 1 9 1 1}$ & 100 & $\mathbf{6 7 1 6 4}$ & 100 & $\mathbf{6 9 5 3 8}$ & 100 \\
\hline
\end{tabular}




\subsubsection{Total Cost of Production}

Total cost of production included variable costs (summation of all cash and noncash expenses) and fixed costs incurred for pumpkin cultivation. On an average total cost of production for pumpkin cultivation was Tk. 69,538 per hectare of which $9 \%$ was fixed costs and $91 \%$ was variable cost (Table 3.12). It was observed that the total cost of production of pumpkin was higher (Tk. 71,911 per hectare) in Rangpur compared to Gaibandha (Tk. 67,164 per hectare) due to use of high amount of inputs, especially human labour and cowdung.

\subsection{Returns and financial profitability for pumpkin}

The average marketable yield of pumpkin was higher (32.22 t/ha) in Rangpur than Gaibandha (26.85 t/ha). On an average gross return was Tk.169,155/ha. Higher gross return was obtained by Rangpur farmers' (Tk.177, 210/ha) than that of Gaibandha farmers' (Tk.161,100/ha). The yield difference between two districts was only 3.37 tons. On an average, gross margin was Tk.105,608/ per hectare which was higher in Rangpur (Tk.111,734 per hectare) than that of Gaibandha (Tk.99,481 per hectare). Net return followed the similar trend like gross return. The average net return was Tk.99,618

per hectare. The benefit cost ratio (BCR) was 2.43 which was slightly higher for Rangpur (2.46) than Gaibandha (2.40). On the basis of total cost, the cost of production per kilogram of pumpkin was Tk. 2.37 (Table 3.13).

Table 3.13. Per hectare profitability of Pumpkin cultivation

\begin{tabular}{lcccc}
\hline \multicolumn{1}{c}{ Particulars } & Rangpur & Gaibandha & All area \\
\hline A. Yield (Ton/ha) & 32.22 & 26.85 & 29.54 \\
B. Price (Tk./kg) & 5.5 & 6.0 & 5.75 \\
C. Gross return (Tk.) & 177,210 & 161,100 & 169155 \\
D. Total variable cost (Tk.) & 65476 & 61619 & 63548 \\
E. Gross Margin (C-D) & 111,734 & 99481 & 105608 \\
F. Total fixed cost (Tk.) & 6435 & 5545 & 5990 \\
G. Total cost (D+F) & 71911 & 67164 & 69538 \\
H. Net Return (C-G) & 105,299 & 93,936 & 99618 \\
I. BCR (C/G) & 2.46 & 2.40 & 2.43 \\
J. Returns to labour & 5.67 & 5.46 & 5.57 \\
K. Cost of production (Tk./kg) & 2.23 & 2.50 & 2.37 \\
\hline
\end{tabular}

\subsection{Comparative advantages of pumpkin production}

DRC indicates whether the domestic economy has a comparative advantage in pumkin production relative to other countries. If the DRC is greater than one, it 
implies that the economy loses foreign exchange through domestic production of pumpkin (in the sense that it uses more domestic resources than it generates net value added to tradable goods and services), while DRC is less than one implies that the production is efficient and make positive contribution to domestic value addition. The estimates of DRCs for pumpkin are presented in Table 3.14. The DRCs for pumpkin was observed to be less than unity implying that Bangladesh had comparative advantage in pumpkin production for export promotion.

Table 3.14. Domestic resource cost (DRC) of pumpkin cultivation at export parity level

\begin{tabular}{lc}
\hline Items & Pumpkin \\
\hline A. Traded input (Tk/MT) & 379 \\
B. Non-Traded inputs and domestic resources (Tk/MT) & 2083 \\
Human labour & 1028 \\
Mechanical power & 51 \\
Seed & 51 \\
Manure & 210 \\
Pesticides & 153 \\
Irrigation & 350 \\
Int. on operating capital & 42 \\
Land rent & 203 \\
C. Output price (Tk/MT) & 28390 \\
D. Value added (Tradable) (Tk/MT) (C-A) & 28011 \\
E. DRC (B/D) & $\mathbf{0 . 0 7 4}$ \\
\hline
\end{tabular}

Source: Author's calculation

3.9. Estimated production function and resource use efficiency

Table 3.15. Estimated value of coefficients and related statistics of Cobb-Douglas production function for pumpkin cultivation

\begin{tabular}{lccc}
\hline \multicolumn{4}{c}{ Dependent variable: LNOUTPUT } \\
\hline \multicolumn{4}{c}{ Included observations: 120 } \\
\hline Variable & Coefficient & Std.Error & t-statistic \\
\hline LNLABOUR & 0.342 & 0.111 & $3.086^{* * *}$ \\
LNSEED & 0.321 & 0.170 & $1.890^{*}$ \\
LNBIOFERT & 0.452 & 0.169 & $2.673^{* * *}$ \\
LNCHEMFERT & 0.235 & 0.241 & 0.976 \\
CONSTANT & 8.068 & 1.219 & $6.620^{* * *}$ \\
\hline R-squared & & 0.652 & \\
F-ratio & & $1.861^{* *}$ & \\
Returns to scale $\left(\mathrm{b}_{1+} \mathrm{b}_{2+} \mathrm{b}_{3+} \mathrm{b}_{4+} \mathrm{b}_{5)}\right.$ & & 1.428 \\
\hline
\end{tabular}

Note: $* * *, * *$ and $*$ indicate significant at $1 \%$ and $5 \%$ and $10 \%$ level respectively 
Results of the production function indicate output was positively related to labour, bio-fertilizer, chemical fertilizer and seed. This implies that output increased with the increase of the quantities of the inputs. The value of the coefficient of determination $\left(\mathrm{R}^{2}\right)$ was 0.652 which indicated that around $65 \%$ of the variation in output was explained by the independent variables included in the model. The value of $\mathrm{F}$ was 1.861 which was significant at $5 \%$ level indicates the good fit of the model. The total elasticity (sum of the partial elasticity 1.428) showed increasing returns to scale implies that when all other variables are held constant, a unit increase in one of them results in more than proportionate increase in output

Table 3.16. Estimated resource use efficiency in pumpkin production

\begin{tabular}{l|lll|l|l|l|l}
\hline Variable & Coefficients & MPP & Py & MVP & MFC & MVP/MFC \\
\hline Labour & 0.342 & 82.809 & 5.75 & 476.151 & 250 & 1.905 \\
Seed & 0.321 & 8862.000 & 5.75 & 50956.500 & 1405 & 36.268 \\
Bio-fertilizer & 0.452 & 1.076 & 5.75 & 6.186 & 0.5 & 12.373 \\
Chemical & 0.235 & & 5.75 & & & \\
fertilizer & & 21.059 & & 121.089 & 15.54 & 7.792 \\
\hline
\end{tabular}

Table 3.16 shows that the ratios of MVP and MFC are greater than unity for all inputs indicating that such inputs were underutilized. Farmers in the study area used too little input to cultivate pumpkin that means the cost of using these inputs is less than the value of marginal product. This suggests that farmers can incur more cost for these inputs to be efficient.

\section{Conclusions}

The study revealed that Farmers in the char land were highly dependent on agriculture for their livelihood. They were not much educated. Their livelihood status was low but they are now improving their livelihood by cultivating pumpkin on sandbar. Net returns of pumpkin cultivation on sandbar were positive and BCR was also encouraging. However, the highest net return was estimated for Rangpur followed by Gaibandha. The highest benefit cost ratio (BCR) was also for Rangpur followed by Gaibandha. DRC results indicated that Bangladesh had comparative advantage for producing pumpkin as the estimates of domestic resource cost (DRC) was less than one implied that the production of pumpkin would be highly efficient for export promotion. Farmers are produced at increasing returns to scale. Farmers in the study area used too little input to cultivate pumpkin that means the cost of using these inputs is less than the value of marginal product. This suggests that farmers can incur more cost for these inputs to be efficient and can increase pumpkin production. The country has got some natural advantages like fertile soil, favorable climatic condition, and abundant supply of inexpensive labour force. However, Bangladesh seemed to 
have a high potential for growing pumpkin crop. Pumpkin production could be expanded for export promotion by using more improved technology as the country's demand. So emphasis should also be given on local production of pumpkin as the export parity is favorable for the country.

\section{References}

Arifur, R. M. and M. R. Munsur. 2011. Resource and livelihood practices of Char Dwellers: A case study of an attached char. In: Proceedings of the 3rd International conference on water and flood management, ICWFM-2011, Dhaka, Swasti Printers Nilkhet, Vol. 1, Pp 207-213.

Atanu R., A. N. M. R. Karim, T. Hristovska, and G. W. Norton. 2011. Impact Assessment of Pheromone Traps to Manage Fruit Fly on Sweet Gourd Cultivation. Bangladesh J. Agril. Res. 36(2): 197-203.

BBS. 2015. Bangladesh Bureau of Statistics, Statistical Year Book of Bangladesh, Statistics Division, Ministry of planning, Government of People's Republic of Bangladesh, Dhaka.

Callinor, A., T. Wheeler, C. Garforth, P. Craufund, A. Kassam. 2007. Assessing the Vulnerability of Food Crops Systems in Africa to Climate Change. Springer. J. of Climate Change. 83:381-399.

EGIS - Environmental and Geographical Information Services. 2000. Riverine Chars in Bangladesh: Environmental dynamics and Management issues, University Press Limited,Dhaka, Bangladesh.

FAP - Flood Action Plan- 16/19. 1994. Char-land study overview: Summary report, flood plan coordination organization, Ministry of Irrigation Water Development and Flood Control, Dhaka(Prepared by Irrigation support project for Asia and the Near East).

Freund J. E. and F. J. Williams. 1983. Modern Business Statistics, London: Pitman.

Islam, S. N., S. Singh, H. Shaheed and S. Wei. 2010. Settlement relocation in the charlands of Padma River basin in Ganges delta, Bangladesh. In: Front. Earth Sci. China 2010, 4(4): $393-402$

Islam S. N. , R. U. Karim, N. Newaz, S. I. Alam, Z. Akter, S. Akter, A. Rouf , H. Shaheed. 2011. Padma Bridge in Bangladesh - An Opportunity and Challenges for Char-Land Livelihoods Sustainability: A Case Study on Char-Janajat in the Ganges Active Delta. Asia-Pacific Journal of Rural Development.21(2): 119-144.

Mbata, J. N. and J. C. Matewa. 1983. "Resource Use Effi-ciency among Small-Scale Farmers in Selected Areas of Western Kenya", Trpenlandwirt, Germany, Vol. 94 (2)

Nutritional Surveillance Project (2003). Life in the Chars in Bangladesh Improving nutrition and supporting livelihoods through homestead food production. Bulletin No. 14.

Olomla, A. 1991. Capture Fisheries and Aquaculture in Nigeria: A Comparative Economic Analysis, Issues in Afri-can Rural Development, Vol. 1, Winrock Institute for Agri-cultural Development 
PAB. 2014. Annual report 2014, Practical Action Bangladesh. P-04.

Rahman S. and J. Davis. 2005. A survey of rural livelihood and enterprise development opportunities in the Chars, Bangladesh. DFID Poverty Oriented Research Programme R8369 (NRI: C1731).

Nahar S. L., M. Akteruzzaman, A. K. M.A. Al-Amin. 2016. Sweet Gourd Production under Sandbar Cropping Practices: A Case Study in Sundorganj of Gaibandha District in Bangladesh. Progressive Agriculture. 27 (3): 320-326.

Thompson, P. and Tod, I. (1998). Mitigation flood losses in the floodplains of Bangladesh: Disaster Prevention and Management. 2(2): 113 - 123. 
